\title{
AKIBAT HUKUM TERHADAP PUTUSAN BEBAS (VRIJSPRAAK) BAGI WARGA NEGARA ASING (Studi Putusan Pengadilan Negeri Denpasar Nomor 748/Pid.Sus/2016/PN DPS)
}

\author{
Oleh: \\ Ida Ayu Nyoman Sri Candra Purnami ${ }^{1}$
}

\begin{abstract}
The high flow of globalization and the easiness of obtaining visas for foreign citizens can increase the income of a country engaged in tourism. This phenomenon does not always have a positive impact for the country of Indonesia because many foreigners were found residing in the territory of Indonesia without having a valid and legal immigration stay permit. Many of these foreign citizens were convicted legal cases in Indonesia, it is therefore necessary to study the legal consequences of the free judgment for the foreign citizens. This study was conducted to examine the legal basis for the imposition of free judgment against foreign citizens and the implementation of the Denpasar District Court Decision Number 748/Pid.Sus/2016/PN DPS on the free judgment against a foreign citizen. This study is an empirical juridical study that examines the legal consequences caused after the abolition of free judgment on foreigner (Case study of Denpasar District Court No. 748/ Pid.Sus / 2016 / PN DPS). Based on the result of this study, was found that according to Law Number 8 Year 1981 regarding Criminal Procedure Law and law of the republic of Indonesia Number 6 Year 2011 on Immigration, foreigners who live in the territory of the Republic of Indonesia who do not have a valid and legal immigration stay permit can be given immigration administrative action in the form of detention. Whereas foreign citizens who are secured and still hold immigration stay permit until the completion of the judicial process and given free judgment, the foreigners may remain in the territory of the Republic of Indonesia until the validity period of their stay permit expires. Meanwhile, for foreign citizens who have been subjected to free judgment and still hold immigration permit, the Public Prosecutor may request the Immigration Civil Service Investigator to perform the act of detention to those foreign citizens.
\end{abstract}

\section{Keywords: Free Judgment, Detention, Immigration Stay Permit}

Abstrak
Tingginya arus globalisasi dan kemudahan memperoleh visa bagi warga negara
asing dapat meningkatkan pendapatan suatu negara yang bergerak dalam bidang
kepariwisataan. Fenomena initidakselaluberdampakpositifbaginegara Indonesia
karena banyak ditemukan orang asing yang berada di wilayah Indonesia tidak
memiliki izin tinggal keimigrasian yang sah dan masih berlaku. Banyak diantara
warga negara asing tersebut tersandung kasus hukum di Negara Indonesia,
sehingga perlu dikaji akibat hukum yang ditimbulkan atas Putusan Bebas bagi

1 Kementerian Hukum dan HAM RI, Direktorat Jenderal Imigrasi, Denpasar Bali, email: tugegcandra@ gmail.com 
warga negara asing tersebut. Penelitian ini dilakukan untuk mengkaji dasar hukum penjatuhan putusan bebas terhadap warga negara asing dan pelaksanaan Putusan Pengadilan Negeri Denpasar Nomor 748/Pid.Sus/2016/PN DPS atas putusan bebas terhadap seorang warganegara asing. Penelitian ini merupakan penelitian yuridis empiris yang mengkaji akibat hukum yang ditimbulkan setelah dijatuhkannya Putusan Bebas terhadap orang asing (Studi kasus terhadap Pengadilan Negeri Denpasar Nomor 748/Pid.Sus/2016/PN DPS). Berdasarkan hasil penelitian ini ditemukan bahwa menurut Undang-Undang Nomor 8 Tahun 1981 Tentang Hukum Acara Pidana dan Undang-Undang Republik Indonesia Nomor 6 Tahun 2011 Tentang Keimigrasian, orang asing yang tinggal di wilayah Negara Republik Indonesia yang tidak memiliki izin tinggal keimigrasian yang sah dan berlaku dapat dilakukan Tindakan Administratif Keimigrasian berupa pendetensian. Sedangkan warga negara asing yang saat diamankan dan hingga proses peradilan selesai masih memiliki izin tinggal keimigrasian dan dijatuhi putusan bebas, maka orang asing tersebut dapat tetap tinggal di wilayah Negara Republik Indonesia hingga masa berlaku izin tinggalnya habis. Sementara bagi orang warga negara asing yang telah dijatuhi putusan bebas dan masih memiliki izin tinggal keimigrasian namun oleh Penuntut Umum dilakukan upaya hukum kasasi, Penuntut Umum dapat meminta kepada Penyidik Pegawai Negeri Sipil Keimigrasian untuk melakukan tindakan pendetensian atas warga negara asing tersebut.

\section{Kata kunci: Putusan bebas, pendetensian, izin tinggal keimigrasian}

\section{PENDAHULUAN}

Kekuasaan kehakiman yang bebas dan merdeka (the independent of judiciary) merupakan salah satu akar berdirinya suatu negara hukum dan unsur berdirinya sebuah negara demokrasi, dimana kekuasaan kehakiman yang merdeka bertugas menjadi pengawal konstitusi. ${ }^{2}$ Berdasarkan ketentuan UndangUndang Dasar Negara Republik Indonesia dalam Pasal 24 Ayat (1) disebutkan bahwa "kekuasaan kehakiman merupakan kekuasaan kehakiman yang merdeka untuk menyelenggarakan peradilan guna menegakkan hukum dan keadilan." 3

2 A.Mukti Arto, 2001,Konsepsi Ideal Mahkamah Agung, Yogyakarta: Pustaka Pelajar, hlm. 20

3 Fence M. Wantu, Kendala Hakim dalam Menciptakan Kepastian Hukum, Keadilan
Hal ini dipertegas kembali dalam Pasal 1 Undang-Undang Nomor 4 Tahun 2004 tentang Kekuasaan Kehakiman, yang menilai kekuasaan kehakiman sebagai kekuasaan negara yang merdeka untuk menyelenggarakan peradilan guna menegakkan hukum dan keadilan berdasarkan Pancasila, demi terselenggaranya negara hukum Republik Indonesia.

Kekuasaan kehakiman yang bebas dan merdeka berjalan sesuai dengan peraturan perundang-undangan menunjukkan bahwa kekuasaan kehakiman bebas dari intervensi pihak mana pun, baik secara kelembagaan

dan Kemanfaatan di Peradilan Perdata, Mimbar Hukum, vol. 25, nomor 2, edisi Juni 2013,https://journal.ugm.ac.id/jmh/ article/view/16092/10638, diakses tanggal 25 Agustus 2017 
maupun dalam proses peradilan hingga dijatuhkannya putusan pengadilan. Indonesia sebagai negara hukum menaruh perhatian besar pada proses peradilan, yang mana peradilan merupakan tempat untuk mencari keadilan bagi masyarakat Indonesia. Dalam menjatuhkan putusan akhir (vonnis), seorang hakim yang baik akan berpedoman pada nilai-nilai kebenaran, keadilan dan kejujuran. Kitab Undang-Undang Hukum Acara Pidana dalam Pasal 1 butir 11 memuat 3 (tiga) jenis pernyataan hakim yang dikemukakannya di depan sidang pengadilan yang merupakan isi dari putusan pengadilan yang dapat berupa pemidanaan, putusan bebas dan putusan lepas dari segala tuntutan hukum sesuai tatacara yang diatur dalam KUHAP.

Sebelum seorang hakim menjatuhkan vonis atas suatu perkara, hakim akan melakukan pengkajian dengan penuh kecermatan dan kejelian terhadapsetiapargumentasi hukum dari penuntut umum dan penasihat hukum terkait kesalahan yang didakwakan kepada terdakwa disertai dengan pengecekan terhadap setiap barang bukti yang diajukan dalam sidang pengadilan. Bilamana dalam proses pengkajian tersebut, menimbulkan ketidakyakinan maupun keragu-raguan hakim, maka hakim dapat menjatuhkan vonis putusan bebas kepada terdakwa ${ }^{4}$. Namun, apabila seorang hakim keliru

4 Leden Marpaung, 1995, Putusan Bebas Masalah dan Pemecahannya, Jakarta: Sinar Grafika, hlm. 50 dalam menjatuhkan putusan bebas maka hakim tersebut dapat di mintakan pertanggungjawaban secara yuridis karena telah salah dalam menerapkan hukum. ${ }^{5}$ Hal ini menunjukkan, argumentasi dan interpretasi hakim terhadap suatu kasus akan sangat menentukan putusan akhir yang dikeluarkan.

Interpretasi hakim terhadap suatu kasus akan sangat mempengaruhi vonis yang dijatuhkan, sehingga sering kali keobjektifan seorang hakim menjadi perdebatan terutama dalam hal penjatuhan putusan bebas. Bagi praktisi hukum dan ahli hukum, putusan bebas yang dijatuhkan oleh hakim akan mengundang polemik, terutama yang berkaitan dengan penerapan hukumnya. Persoalan tersebut muncul karena adanya perbedaan pendapat, di satu pihak Jaksa Penuntut Umum telah menyatakan terdakwa bersalah sesuai dengan isi dakwaannya, namun di sisi lain hakim menolak pendapat penuntut umum, dan menyatakan terdakwa tersebut bebas dari dakwaan. Pada prinsipnya perbedaan pandangan dan sikap atas putusan bebas yang dijatuhkan hakim merupakan sesuatu yang wajar. Dimana dalam menegakkan keadilan bukanlah sesuatu yang mudah, karena tidak dapat memuaskan semua pihak. Secermat apapun putusan tersebut,

5 Darmoko Yuti Witanto dan Arya Putra Negara Kutawaringin, 2013, Diskresi Hakim Sebuah Instrumen Menegakkan Keadilan Substantif dalam Perkara-Perkara Pidana, Bandung: Penerbit Alfabeta, hlm. 198 
bagi yang kalah atau dihukum pasti akan menganggap putusan tersebut tidak adil. $^{6}$

Penjatuhan Putusan Bebas kepada terdakwa dapat terjadi bilamana hakim sebagai corong undang-undang berpendapat perbuatan yang didakwa kepada terdakwa tidak terbukti secara sah dan meyakinkan sebagai suatu kesalahan ${ }^{7}$. Hal ini dapat terjadi apabila menurut Hakim tidak dipenuhinya syarat minimum alat bukti atau tidak ada alat bukti lain yang menguatkan alat bukti utama. Meskipun telah dipenuhinya syarat minimum alat bukti, namun hakim tidak meyakini akan kesalahan terdakwa maka atas dakwaan tersebut dapat pula dijatuhi putusan bebas. Dalam menjatuhkan putusan bebas, hakim juga akan berpedoman pada terpenuhinya unsurunsur pertanggungjawaban pidana, diantaranya tidak ada alasan pemaaf, kemampuan bertanggungjawab serta perbuatan yang berupa kelalaian ataupun sengaja. Terhadap putusan bebas tersebut, terdakwa yang berada di sel tahanan akan dilepaskan oleh jaksa setelah putusan pengadilan dibacakan.

Namun, berdasarkan ketentuan Pasal 191 Ayat (3) bilamana terdapat alasan lain yang sah, seorang terdakwa

6 Sahlan Said, 1995, Kemandirian Kekuasaan Kehakiman-Pengalaman Praktek Menuju Kemandirian Hakim Tolok Ukur dan Kendalanya, Makalah dalam seminar 50 Tahun Kemandirian Kekuasaan Kehakman di Indonesia, Yogyakarta: Universitas Gajah Mada, hlm.2

7 Pasal 191 Ayat (1) Kitab Undang-Undang Hukum Acara Pidana dapat tetap ditahan meskipun sudah dijatuhi putusan bebas oleh pengadilan. Berdasarkan latar belakang yang telah diuraikan tersebut, berikut rumusan masalah yang diangkat dalam penelitian ini sebagai berikut:

1. Bagaimanakah dasar hukum penjatuhan putusan bebas terhadap warga negara asing?

2. Bagaimanakah pelaksanaan Putusan Pengadilan Negeri Denpasar Nomor 748/Pid. Sus/2016/PN DPS atas putusan bebas terhadap seorang warganegara asing?

Orisinalitas penelitian mengenai pelaksanaan Putusan Pengadilan Negeri Denpasar Nomor 748/Pid. Sus/2016/PN DPS dilakukan dengan membandingkan beberapa penelitian lain, diantaranya:

1. "Putusan Hakim dalam Penegakan Hukum di Indonesia" yang ditulis oleh Josef $\mathrm{M}$ Monteiro. ${ }^{8}$ Dalam penelitian tersebut dipaparkan bahwa Hakim tidak hanya sebagai corong Undang-Undang namun juga sebagai penemu hukum. Penelitian tersebut juga mempertegas kewenangan yang dimiliki hakim untuk memeriksa dan memutus suatu perkara yang telah diajukan kepadanya. Dalam memutus suatu perkara, hakim

8 Josef M. Monteiro, 2007, Putusan Hakim dalam Penegakan Hukum di Indonesia, Jurnal Hukum Pro Justisia, edisi April 2007, Volume 25 Nomor 2,http://journal.unpar.ac.id/index. php/projustitia/article/view-File/1132, diakses tanggal 24 Agustus 2017 
berpedoman pada ilmu hukum, teori hukum dan filsafat hukum agar tercipta putusan-putusan yang berkualitas. Penelitian tersebut berbeda dengan penelitian ini, karena dalam penelitian ini lebih menekankan kepada akibat hukum putusan bebas bagi warganegara asing.

2. "Pelaksanaan Undang-Undang Nomor 6 Tahun 2011 Tentang Keimigrasian mengenai Tanggung Jawab Penjamin atas Keberadaan dan Kegiatan Orang Asing di Bali" yang ditulis oleh Ngurah Mas Wijaya Kusuma. Penelitian yang ditulis oleh Ngurah Mas Wijaya Kusuma berfokus pada tanggung jawab yang dimiliki oleh Penjamin yang berkaitan dengan keberadaan dan kegiatan yang dilakukan oleh Warga Negara Asing selama berada di Bali berdasarkan ketentuan dalam UndangUndang Nomor 6 Tahun 2011 Tentang Keimigrasian ${ }^{9}$. Terdapat perbedaan antara penelitian yang ditulis oleh Ngurah Mas Wijaya Kusuma dengan penelitian ini, dimana Penelitian Ngurah Mas

9 Wijaya Kusuma, Ngurah Mas. PELAKSANAAN UNDANG-UNDANG NOMOR 6 TAHUN 2011 TENTANG KEIMIGRASIANMENGENAITANGGUNG JAWAB PENJAMIN ATAS KEBERADAAN DAN KEGIATAN ORANG ASING DI BALI. Jurnal Magister Hukum Udayana (Udayana Master Law Journal), vol. 3 no. 3 edisi September 2014. <https://ojs.unud.ac.id/ index.php/jmhu/article/view/10950>. diakses tanggal 24 Agustus 2017. doi: $<$ https://doi. org/10.24843/JMHU.2014.v03.i03.p12.
Wijaya Kusuma menekankan pada tanggungjawab Warga Negara Indonesia sebagai penjamin keberadaan dan kegiatan orang asing di Bali, sedangkan dalam penelitian ini lebih menekankan pada akibat hukum yang ditimbulkan setelah dijatuhkannya putusan bebas bagi warga negara asing.

Adapun tujuan dari penulisan jurnal ilmiah ini dikategorikan menjadi dua yaitu tujuan umum dan tujuan khusus. Tujuan umum dalam penelitian iniadalahuntukmenganalisismengenai putusan bebas yang dijatuhkan oleh Hakim terhadap warga negara asing yang berada di wilayah Indonesia. Tujuan khusus dalam penelitian ini untuk mengkaji akibat hukum yang ditimbulkan setelah penjatuhan putusan bebas terhadap warga negara asing studi kasus terhadap Putusan Pengadilan Negeri Denpasar Nomor 748/Pid.Sus/2016/PN DPS.

\section{METODE PENELITIAN}

Metode yang digunakan untuk melakukan penelitian ini menggunakan pendekatan yuridis empiris, yang mana penelitian ini mengkaji akibat hukum yangditimbulkansetelahdijatuhkannya putusan bebas terhadap warga negara asing yang melakukan tindakan pidana. Berdasarkan ketentuan pada Pasal 191 Ayat (3) ditegaskan bahwa "Dalam hal sebagaimana dimaksud dalam Ayat (1) dan Ayat (2), terdakwa yang ada dalam status tahanan diperintahkan 
untuk dibebaskan seketika itu juga kecuali karena ada alasan lain yang sah, terdakwa perlu ditahan". Ketentuan yang di atur dalam Pasal 191 Ayat (3) berlaku juga terhadap warga negara asing yang telah dijatuhi putusan bebas oleh pengadilan. Penelitian ini bersifat deskriptif dengan menjabarkan mengenai akibat hukum yang ditimbulkan bagi warga negara asing yang telah dijatuhi putusan bebas berdasarkan Putusan Pengadilan Negeri Denpasar Nomor 748/Pid.Sus/2016/PN DPS.

Penelitian ini menggunakan data primer dan data sekunder. Data primer yang digunakan memuat hasil pengamatan yang dilakukan secara langsung terhadap warga negara asing yang telah dijatuhi putusan bebas oleh Pengadilan Negeri Denpasar. Sedangkan data sekunder terdiri dari bahan hukum primer dan bahan hukum sekunder, bahan hukum primer yang digunakan berupa UndangUndang Nomor 8 Tahun 1981 tentang Kitab Undang-Undang Hukum Acara Pidana dan Undang-Undang Republik Indonesia Nomor 6 Tahun 2011 tentang Keimigrasian. Sedangkan bahan hukum sekunderyang digunakan dalam penelitian ini berupa literatur mengenai putusan bebas, proses pemidanaan dan tindakan pendetensian yang dilakukan oleh pejabat Imigrasi.

\section{Proses}

pengumpulan

bahan hukum dalam penelitian ini menggunakan teknik studi kepustakaan. Berdasarkan teknik studi kepustakaan, setiap bahan hukum yang berkaitan dengan substansi penelitian dikumpulkandandicatatyangkemudian digunakan dalam penelitian ini dengan mencantumkan sumber rujukan yang jelas. Pencantuman bahan hukum yang jelas dapat mencegah terjadinya plagiasi. Bahan hukum dianalisis secara kualitatif, yakni menguraikan akibat hukum yang ditimbulkan setelah dijatuhkannya putusan bebas terhadap warga negara asing berdasarkan Putusan Pengadilan Negeri Denpasar Nomor 748/Pid.Sus/2016/PN DPS yang dijabarkan dengan menggunakan metode deskriptif analitis.

\section{HASIL DAN PEMBAHASAN}

3.1 Dasar hukum penjatuhan putusan bebas terhadap warga negara asing.

Hakim dalam sidang pengadilan dapat menjatuhkan vonis bebas kepada warga negara asing apabila hakim berpendapat bahwa kesalahan atau perbuatan yang dilakukan oleh warga negara asing tersebut tidak dapat dibuktikan secara sah dan meyakinkan sebagai suatu perbuatan pidana $^{10}$. Seorang terdakwa tidak terbukti bersalah selama sidang pengadilan dapat disebabkan karena tidak terpenuhinya minimum alat bukti. Sebagai contoh dalam proses persidangan, dalam sidang pengadilan hanya ditemukan keterangan tersangka tanpa dikuatkan oleh alat bukti lain,

10 Ansori Sabuan, dkk. 1990, Hukum Acara Pidana, Angkasa, Bandung, hlm. 198 
dan atau telah dipenuhinya minimum alat bukti namun hakim tidak yakin akan kesalahan terdakwa, maka atas tuntutan tersebut hakim dapat pula menjatuhkan putusan bebas.

Putusan bebas yang dijatuhkan oleh hakim dalam persidangan tidak dengan tegas menyatakan terdakwa tidak bersalah, namun menunjukkan tidak dapat dibuktikannya kesalahan terdakwa di muka persidangan. Hal ini berdasarkan ketentuan yang tercantum dalam Pasal 183 KUHAP yang menyatakan "Hakim tidak boleh menjatuhkan pidana kepada seorang kecuali apabila sekurangkurangnya dua alat bukti yang sah ia memperoleh keyakinan bahwa suatu tindak pidana benar-benar terjadi dan bahwa terdakwa lah yang bersalah melakukannya." Indonesia menganut sistem pembuktian menurut Undangundang yang negatif, disebut negatif karena untuk membuktikan suatu dakwaan diperlukan minimal alat bukti yang sah berdasarkan undang-undang serta menurut keyakinan hakim. Seorang terdakwa yang berada dalam status penahanan, apabila dijatuhkan putusan bebas maupun putusan lepas dari segala tuntutan hukum oleh Pengadilan akan diperintahkan untuk dibebaskan seketika itu juga, kecuali dalam alasan lain yang sah seorang terdakwa tetap harus ditahan. Pengaturan mengenai dibenarkannya alasan tersebut diatur dalam Pasal 191 Ayat (3) KUHAP yaitu "Dalam hal sebagaimana dimaksud dalam Ayat
(1) dan Ayat (2), terdakwa yang ada dalam status tahanan diperintahkan untuk dibebaskan seketika itu juga kecuali karena ada alasan lain yang sah, terdakwa perlu ditahan".

Pelaksanaan

penahanan

bagi seorang terdakwa yang telah diputus bebas oleh pengadilan dapat dibenarkan bilamana dilandasi oleh dasar hukum yang jelas. Hal ini harus berdasarkan pada ketentuan hukum yang bersifat lebih khusus terutama pada tindak pidana khusus. Apabila dalam ketentuan yang diatur dalam tindak pidana khusus terdapat hal-hal yang menjadikan seorang terdakwa tetap harus ditahan, maka terhadap penahanan tersebut penyidik wajib melaporkan tindakan tersebut kepada Ketua Pengadilan. Kewajiban untuk melaporkan tindakan penahanan tersebut kembali dipertegas dalam penjelasan Pasal 193 Ayat (3) KUHAP yang menyatakan "Jika terdakwa tetap dikenakan penahanan atas dasar alasan lain yang sah, maka alasan tersebut secara jelas diberitahukan kepada Ketua Pengadilan Negeri sebagai pengawas dan pengamat terhadap pelaksanaan putusan pengadilan”.

Bila ditinjau lebih lanjut, dalam hal penjatuhan bebas terhadap terdakwa yang merupakan warga negara asing perlu diperhatikan pula izin tinggal keimigrasian yang dimiliki oleh orang asing tersebut. Hal inilah yang dapat menjadi pertimbangan bagi Pengadilan setelah dijatuhkannya putusan bebas. Orang asing yang sejak 
awal diamankan baik oleh Penyidik Pegawai Negeri Sipil Keimigrasian maupun penyidik Polri tidak memiliki izin tinggal keimigrasian dan masih berada di wilayah negara Indonesia dapat ditempatkan pada Ruang Detensi Imigrasi atau Rumah Detensi Imigrasi hal ini sesuai dengan kewenangan yang dimiliki oleh pejabat Imigrasi yang tertuang dalam ketentuan Pasal 83 Ayat (1) Undang-Undang Nomor 6 Tahun 2011 tentang Keimigrasian ${ }^{11}$.

\subsection{Pelaksanaan}

Putusan

Pengadilan Negeri Denpasar Nomor 748/Pid.Sus/2016/ PN DPS atas putusan bebas terhadap warga negara asing.

Berdasarkan Putusan Pengadilan Negeri Denpasar Nomor 748/Pid. Sus/2016/PN DPS pada tanggal 17 Nopember 2016 menjatuhkan putusan bebas terhadap seorang warga negara asing berkebangsaan Italia yang didakwa oleh Jaksa Penuntut Umum dengan ketentuan UndangUndang Nomor 6 Tahun 2011 tentang Keimigrasian Pasal 122 Huruf a yang berbunyi: "dengan sengaja menyalahgunakan atau melakukan kegiatan yang tidak sesuai dengan maksud dan tujuan pemberiannya itu. Dalam amar putusan pengadilan

11 Imam Bahri, Pengawasan Keimigrasian Terhadap Orang Asing Dalam Rangka Pendeportasian Ditinjau Dari Undang-Undang Nomor 6 Tahun 2011 Tentang Keimigrasian (Studi Di Kantor Imigrasi Kelas I Polonia Medan), USU LAW JOURNAL, vol. 1 no. 1 , 2013, https://jurnal.usu.ac.id/index.php/law/ article/view/3965, diakses tanggal 23 Agustus 2017
Nomor 748/Pid.Sus/2016/PN DPS diputuskan beberapa hal sebagai berikut:

1. Menyatakan terdakwa Carmine Sciaudone tidak terbukti secara sah dan meyakinkan bersalah melakukan tindak pidana dalam dakwaan tindak pidana yang disampaikan oleh ke dubes Republik Indonesia. Menyatakan terdakwa

CARMINE SCIAUDONE tidak terbukti secara sah dan meyakinkan bersalah melakukan tindak pidana dalam dakwaan tunggal Jaksa Penuntut Umum;

2. Membebaskan terdakwa CARMINE SCIAUDONE dari dakwaan tersebut;

3. Memulihkan hak-hak terdakwa dalam kemampuan, kedudukan dan harkat serta martabatnya;

4. Memerintahkan agar terdakwa di keluarkan dari tahanan setelah putusan ini diucapkan;

5. Menetapkan agar barang bukti berupa:

- 1 (satu) buah Paspor Kewarganegaraan Italia Nomor : YA3244795 atas nama CARMINE SCIAUDONE yang diterbitkan tanggal 27 Desember 2011 dan berlaku sampai dengan 26 Desember 2021;

- 1 (satu) unit telepon genggam merek sony;

Dikembalikan kepada 


\section{terdakwa}

- 1 (satu) unit alat Proyektor Merek Sony;

Dikembalikan kepada saksi Francesco Baffa

- 1 (satu) berkas Dokumen Manifest Kapal Dragon 130

- 1 (satu) berkas Kontrak Kerja Kapal Dragon 130 dengan Ibu Prameswari Gita Semaradani, S.E., MSc.A.k.

Dikembalikan kepada saksi Prameswari Gita Semaradani, S.E., MSc.

\section{A.k.}

- 1(satu) buah dokumen foto kegiatan Carmine Sciaudone pada saat diamankan tanggal 22 Mei 2016 dari lokasi kejadian Kapal Dragon 130;

- 1 (satu) buah Video kegiatan Carmine Sciaudone pada saat diamankan tanggal 22 Mei 2016 dari lokasi kejadian Kapal Dragon 130.

Dikembalikan kepada saksi I Made Andi Kurnia, S.E.

6. Membebankan biaya perkara kepada Negara

Berdasarkan amar Putusan

Pengadilan Negeri Denpasar Nomor 748/Pid.Sus/2016/PNDPSpadatanggal 17 Nopember 2016 telah dilaksanakan sebagian oleh Jaksa Penuntut Umum.
Jaksa Penuntut Umum mengeluarkan Saudara Carmine Sciaudone dari Lembaga Pemasyarakatan Kelas II A Kerobokan pada hari Kamis, 17 Nopember 2016 Pukul 23.00 WITA, sedangkan untuk barang bukti yang lain seperti : 1 (satu) buah Paspor Kewarganegaraan Italia Nomor : YA3244795 atas nama CARMINE SCIAUDONE yang diterbitkan tanggal 27 Desember 2011 dan berlaku sampai dengan 26 Desember 2021 dan 1 (satu) unit telepon genggam merek sony milik Carmine Sciaudone belum dikembalikan kepadanya. Hal ini merujuk amar putusan yang tidak memerintahkan untuk segera mengembalikan barang bukti setelah sidang selesai. Hal ini diperkuat kembali dengan ketentuan Pasal 194 ayat (3) KUHAP yang menjelaskan bahwa "perintah penyerahan barang bukti dilakukan tanpa disertai suatu syarat apapun kecuali dalam hal putusan pengadilan belum mempunyai kekuatan hukum tetap". Putusan Pengadilan Negeri Denpasar Nomor 748/Pid.Sus/2016/PN DPS dinyatakan belum memiliki kekuatan hukum tetap, hal ini dikarenakan Jaksa Penuntut Umum telah mengajukan upaya hukum kasasi sesuai Pasal 244, 245, 248 dan 253 KUHAP sesuai dengan akta permohonan kasasi Penuntut Umum Nomor 748/Akta Pid.Sus/2016/PN Dps tanggal 18 Nopember 2016.

Meskipun saudara Carmine Sciaudone telah dikeluarkan oleh Penuntut Umum dari Lembaga 
Pemasyarakatan kelas II A Kerobokan, namun Carmine Sciaudone tidak dapat secara serta merta terbebas dari sanksi dan dapat tinggal di wilayah Negara Republik Indonesia. Dalam kasus ini, saudara Carmine Sciaudone sejak diamankan dari Kapal Dragon 130 di Dermaga Timur Tempat Pemeriksaan Imigrasi Benoa pada tanggal $22 \mathrm{Mei}$ 2017 sudah tidak memiliki izin tinggal keimigrasian yang sah (overstay) selama 104 hari dan masih berada di wilayah Negara Republik Indonesia sampai dengan saat ini. Ketentuan Pasal 83 Ayat (1) huruf a UndangUndang Nomor 6 Tahun 2011 tentang Keimigrasian menyebutkan bahwa "Pejabat Imigrasi berwenang menempatkan orang asing dalam Rumah Detensi Imigrasi atau Ruang Detensi Imigrasi jika orang asing tersebut berada di Wilayah Indonesia tanpa memiliki izin tinggal yang sah atau memiliki izin tinggal yang tidak berlaku lagi".

Ketentuan mengenai pendetensian orang asing tersebut kembali dipertegas dalam ketentuan Pasal 208 dan Pasal 209 Peraturan Pemerintah Nomor 31 Tahun 2013 tentang Peraturan Pelaksanaan UndangUndang Nomor 6 Tahun 2011 tentang Keimigrasian. Dilaksanakannya Pendetensian terhadap saudara Carmine Sciaudone tidak melanggar amar putusan pengadilan, mengingat dalam Pasal 191 Ayat (3) yang menyebutkan bahwa "dalam hal sebagaimana dimaksud dalam Ayat
(1) dan Ayat (2), terdakwa yang ada dalam status tahanan diperintahkan untuk dibebaskan seketika itu juga kecuali karena ada alasan lain yang sah, terdakwa perlu ditahan". Terhadap saudara Carmine Sciaudone, dibenarkan untuk tetap dilaksanakan proses pendetensian meskipun dalam amar Putusan Pengadilan dinyatakan dibebaskan dari tahanan. Terlebih lagi belum adanya kekuatan hukum tetap atas putusan pengadilan tersebut, mengingat jaksa penuntut umum telah mengajukan upaya hukum kasasi.

Bagi warga negara asing yang berada di wilayah Indonesia dan tidak memiliki izin tinggal keimigrasian yang sah dan berlaku dapat dilakukan Tindakan Administratif Keimigrasian berupa pendetensian berdasarkan ketentuan Pasal 83 Ayat (1) huruf a Undang-Undang Nomor 6 Tahun 2011 tentang Keimigrasian. Berdasarkan alasan inilah, saudara Carmine Sciaudone dapat dikenakan proses pendetensian yang merupakan kewenangan Penyidik Pegawai Negeri Sipil Keimigrasian. Mengingat adanya batas waktu penempatan orang asing di Ruang Detensi Imigrasi ${ }^{12}$, maka Saudara Carmine Sciaudone dapat di titipkan di Rumah Detensi Imigrasi terhitung sejak tanggal 21 November 2016 sebagaimana tercantum dalam Surat Plh. Kepala Kantor Imigrasi

12 Warhan Wirasto, Pelaksanaan Pengawasan Warga Negara Asing Di Wilayah Kerja Kantor Imigrasi Kelas II Belawan berdasarkan UU No. 6 Tahun 2011 Tentang Keimigrasian, USU Law Journal, Vol.4.No.1 edisi Januari 2016, hlm. 168-185 
Nomor W20.EB-GR.03.02-0195

Tanggal 21 Nopember 2016 perihal serah terima WNA a.n. Carmine Sciaudone yang ditujukan kepada Kepala Rumah Detensi Imigrasi Denpasar dan Berita Acara Serah Terima Deteni Nomor : W20.3BGR.03.02-0196 tanggal 21 Nopember 2016.

Hal berbeda akan terjadi apabila seorang warga negara asing yang saat diamankan dan hingga proses peradilan selesai masih memiliki izin tinggal keimigrasian dan dijatuhi putusan bebas, maka warga negara asing tersebut dapat tetap berada di wilayah Negara Republik Indonesia hingga masa berlaku izin tinggalnya habis. Sedangkan terhadap seorang warga negara yang telah dijatuhi putusan bebas dan masih memiliki izin tinggal keimigrasian namun oleh Penuntut Umum dilakukan upaya hukum kasasi, maka berdasarkan hal tersebut Penuntut Umum dapat meminta kepada Penyidik Pegawai Negeri Sipil Keimigrasian untuk melakukan tindakan pendetensian atas warga negara asing tersebut.

\section{KESIMPULAN}

1. Putusan Bebas dapat dijatuhkan oleh Hakim apabila berdasarkan keyakinan hakim dakwaan yang ditunjukkan kepada terdakwa tidak terbukti secara sah dan meyakinkanberdasarkanundangundang sebagai suatu perbuatan pidana. Dalam hal dijatuhkannya putusan bebas, terdakwa yang berada dalam status penahanan dapat dilepaskan seketika itu juga berdasarkan undang-undang sesuai dengan amar putusan yang dikeluarkan. Dalam hal seorang terdakwa setelah diputus bebas namun tetap berada dalam masa tahanan karena suatu dasar alasan lain yang sah, maka wajib untuk melaporkan hal tersebut kepada Ketua Pengadilan sebagai pengawas pelaksanaan putusan pengadilan.

2. Berdasarkan kajian terhadap putusan Pengadilan Negeri Denpasar Nomor 748/Pid. Sus/2016/PN DPS pada tanggal 17 Nopember 2016 terhadap terdakwa yang telah diputus bebas dilepaskan dari tahanan Lembaga Pemasyarakatan Kelas II A Denpasar, namun mengingat terdakwa seorang warga negara asing yang sejak diamankan oleh Penyidik Pegawai Negeri Keimigrasian tidak memiliki izin tinggal keimigrasian yang sah maka terhadap terdakwa berlaku ketentuan Undangundang Nomor 6 Tahun 2011 tentang Keimigrasian. Terdakwa harus tetap berada di ruang detensi imigrasi ataupun Rumah Detensi Imigrasi sesuai dengan kewenangan yang dimiliki oleh Pejabat Imigrasi. 


\section{DAFTAR PUSTAKA}

\section{BUKU}

Arto, A. Mukti, 2001, Konsepsi Ideal Mahkamah Agung, Pustaka Pelajar, Yogyakarta

Marpaung,Leden, 1995, Putusan Bebas Masalah dan Pemecahannya, Sinar Grafika, Jakarta

Sabuan, Ansori, dkk. 1990, Hukum Acara Pidana, Angkasa, Bandung.

Said, Sahlan, 1995, Kemandirian Kekuasaan KehakimanPengalaman Praktek Menuju Kemandirian Hakim Tolok Ukur dan Kendalanya, Makalah dalam seminar 50 Tahun Kemandirian Kekuasaan Kehakiman di Indonesia, Universitas Gajah Mada, Yogyakarta.

Witanto, Darmoko Yuti dan Arya Putra Negara Kutawaringin, 2013, Diskresi Hakim Sebuah Instrumen Menegakkan Keadilan Substantif dalam PerkaraPerkara Pidana, Penerbit Alfabeta, Bandung.

\section{JURNAL}

Bahri, Imam, Pengawasan Keimigrasian Terhadap Orang Asing Dalam Rangka Pendeportasian Ditinjau Dari Undang-Undang Nomor 6 Tahun 2011 Tentang Keimigrasian (Studi Di Kantor Imigrasi Kelas I Polonia Medan), USU LAW JOURNAL, vol. 1 no. 1, 2013, https://jurnal.usu. ac.id/index.php/law/article/view/3965, diakses tanggal 23 Agustus 2017

Monteiro, Josef M., 2007, Putusan Hakim dalam Penegakan Hukum di Indonesia, Jurnal Hukum Pro Justisia, edisi April 2007, Volume 25 No. 2, Bandung Wantu,FenceM.,KendalaHakimdalam Menciptakan Kepastian Hukum, Keadilan dan Kemanfaatan di Peradilan Perdata, Mimbar Hukum, vol. 25, no. 2, edisi Juni 2013, https://journal.ugm.ac.id/ $\mathrm{jmh} /$ article/view/16092, diakses tanggal 25 Agustus 2017

Wirasto, Warhan, Pelaksanaan Pengawasan Warga Negara Asing Di Wilayah Kerja Kantor Imigrasi Kelas II Belawan berdasarkan UU No. 6 Tahun 2011 Tentang Keimigrasian, USU Law Journal, edisi Januari 2016, Vol.4.No.1, Medan

Wijaya Kusuma, Ngurah Mas. PELAKSANAAN U N D A N G - U N D A N G NOMOR 6 TAHUN 2011 TENTANG KEIMIGRASIAN MENGENAI TANGGUNG JAWAB PENJAMIN ATAS KEBERADAAN DAN KEGIATAN ORANG ASING DI BALI. Jurnal Magister Hukum Udayana (Udayana Master Law Journal), vol. 3 no. 3 edisi September 2014. $<$ https://ojs.unud.ac.id/index. php/jmhu/article/view/10950>. diakses tanggal 24 Agustus 2017. 
doi: https://doi.org/10.24843/

JMHU.2014.v03.i03.p12.

PERATURAN PERUNDANG-

UNDANGAN

Undang-Undang Nomor 8 Tahun 1981

tentang Hukum Acara Pidana

Undang-Undang Nomor 6 Tahun 2011

tentang Keimigrasian

Peraturan Pemerintah Nomor 31

Tahun 2013 tentang Peraturan

Pelaksanaan Undang-Undang

Nomor 6 Tahun 2011 tentang

Keimigrasian. 